\title{
ARAŞTIRMA / RESEARCH \\ Comparison of the effects of hyperbaric and normobaric oxygen treatments on the repolarisation parameters of electrocardiography in children with carbon monoxide poisoning
}

Karbonmonoksit zehirlenmesi olan çocuklarda hiperbarik ve normobarik oksijen tedavilerinin elektrokardiyografinin repolarizasyon parametreleri üzerindeki etkilerinin karşılaştırılması

\section{Zafer Bağc1 (D), Abdullah Arslan' (D), Derya Arslan'}

${ }^{1}$ University of Health Sciences, Konya Education and Research Hospital, Department of Pediatrics, ${ }^{3}$ Department of Pediatric Cardiology, Konya, Turkey

${ }^{2}$ Necmettin Erbakan University, Meram Faculty of Medicine, Dept. of Undersea and Hyperbaric Medicine, Konya, Turkey

Cukurova Medical Journal 2021;46(4):1606-1613

\begin{abstract}
Purpose: The aim of this study was to compare the effects of hyperbaric oxygen therapy (HBOT) induced hyperoxygenation and normobaric oxygen therapy (NBOT) on myocardial repolarisation parameters in children with carbon monoxide (CO) poisoning.

Materials and Methods: This prospective study included 77 girls and boys aged 0-18 years who were diagnosed and treated for $\mathrm{CO}$ poisoning. There were no changes in the routine clinical evaluation and treatment practices of patients. Patients who received NBOT $(n=40)$ and HBOT $(n=37)$ were divided into two groups. These groups were compared in terms of their demographic characteristics, carboxyhaemoglobin, lactate, troponin levels and myocardial repolarisation parameters of electrocardiography (ECG) (Tp-e interval, Tp-e dispersion, QTc and Tp-e/QTc ratio).

Results: There were no significant intergroup differences in terms of carboxyhaemoglobin, lactate and troponin levels at the time of admission; admission and posttreatment Tp-e, Tp-e dispersion, corrected QTc and TPe/QTc ratio and post-treatment change rates of each ECG parameter.

Conclusion: There was no intergroup difference in terms of repolarisation parameters of ECG in children with $\mathrm{CO}$ poisoning. The possible reason for this may be myocardial reperfusion damage due to hyper-oxygenation associated with HBOT therapy.
\end{abstract}

Keywords: Carbon monoxide poisoning, electrocardiography, hyperbaric oxygen, child
Öz

Amaç: Bu çalışmanın amacı, karbon monoksit (CO) zehirlenmesi olan çocuklarda hiperbarik oksijen tedavisi (HBOT) ile oluşturulan hiperoksijenasyonun ve normobarik oksijen tedavisinin (NBOT) miyokardiyal repolarizasyon parametreleri üzerindeki etkilerini karşılaştırmaktı.

Gereç ve Yöntem: $\mathrm{Bu}$ prospektif çalışmaya CO zehirlenmesi tanısı konulan ve tedavi edilen 0-18 yaș arası kız ve erkek çocuklar dahil edildi. Hastaların rutin klinik değerlendirme ve tedavi uygulamalarında değişiklik olmadi. Hastalar NBOT yapilanlar $(n=40)$ ve HBOT yapilanlar $(n=37)$ olarak iki gruba ayrildı. Bu gruplar, demografik özellikler, karboksihemoglobin, laktat, troponin düzeyleri ve elektrokardiyografinin (EKG) miyokardiyal repolarizasyon parametreleri (Tp-e aralığı, Tp-e dispersiyonu, QTc ve Tp-e / QTc oranı) yönünden karşılaştırıldı.

Bulgular: Gruplar arasında başvurudaki $\mathrm{COHb}$, laktat, troponin düzeyleri; başvuruda ve tedavi sonrası Tpe, Tpe dağılımı, düzeltilmiş QTc ve TPe/QTc oranları ve her bir EKG parametresinin tedavi sonrası değişim oranları yönünden anlamlı bir farklılık saptanmadı.

Sonuç: CO zehirlenmesi olan çocuklarda EKG repolarizasyon parametreleri açısından gruplar arasında fark yoktu. Bunun olası nedeni, HBOT tedavisi ile ilişkili hiperoksijenasyona bağlı miyokardiyal reperfüzyon hasarı olabilir.

Anahtar kelimeler: Karbonmonoksit zehirlenmesi, elektrokardiyografi, hiperbarik oksijen, çocuk 


\section{INTRODUCTION}

Carbon monoxide (CO) is a colourless, odourless and irritant gas. Poisoning caused by $\mathrm{CO}$ gas due to incomplete combustion of carbon-containing compounds is one of the most common causes of poisoning and complications and deaths associated with poisoning worldwide ${ }^{1}$. Carboxyhaemoglobin $(\mathrm{COHb})$, which is formed due to its high affinity of $\mathrm{CO}$ to haemoglobin, reduces the release of oxygen $\left(\mathrm{O}_{2}\right)$ into tissues and disrupts the respiratory and mitochondrial functions of cells ${ }^{2}$. Electrical, functional and morphological changes of the heart in $\mathrm{CO}$ poisoning can affect the myocardium and coronary arteries, thereby leading to cardiotoxicity. In studies related to myocardial damage in patients with $\mathrm{CO}$ poisoning, nonspecific repolarisation changes and arrhythmias have been observed in electrocardiography $(\mathrm{ECG})^{3,4}$. The sudden deaths cases in $\mathrm{CO}$ poisoning might be due to ventricular arrhythmias $^{3}$. The T-wave on ECG is an indicator of ventricular repolarisation. Studies have investigated Tpeak-Tend interval (time from the peak of the $\mathrm{T}$ wave to the end of the T-wave), Tpeak-Tend dispersion, QT interval and QT dispersion in patients with CO poisoning; these studies showed that increased QT dispersion and increased Tp-e/QT ratio are associated with an increased risk of cardiac arrhythmia ${ }^{5,6}$. It has been shown that ventricular repolarisation abnormality may occur in children with mild CO poisoning before any electrocardiographic arrhythmia develops ${ }^{7}$.

Hyper-oxygenation is essentially the basis of the treatment of $\mathrm{CO}$ poisoning. Hyper-oxygenation is achieved by normobaric oxygen therapy (NBOT), in which atmospheric pressure is applied, or by hyperbaric oxygen therapy (HBOT), which is administered in high pressure units. The goal is to supply sufficient $\mathrm{O}_{2}$ into the circulation to counter the harmful effects of $\mathrm{COHb}$ and tissue hypoxia ${ }^{8}$. To our knowledge, there are no studies in which the effects of HBOT and NBOT on ECG repolarisation parameters are compared in cases with $\mathrm{CO}$ poisoning.

The aim of this study is to compare the effects of HBOT-induced and NBOT-induced hyperoxygenation on myocardial repolarisation parameters with NBOT in children with CO poisoning and to establish the potential relationships of these parameters with blood gas parameters. The hypothesis of this study is about; HBOT being more effective than NBOT on myocardial repolarization parameters in children with CO poisoning. Revealing this relationship would contribute positively to the treatment of children with $\mathrm{CO}$ poisoning.

\section{MATERIALS AND METHODS}

\section{Study group}

Children aged 0-18 years who were diagnosed with CO poisoning in the Pediatric Emergency Clinic were included in this prospective study. The study was held in Konya Education and Research Hospital Hospital, which has the only hyperbaric facility in which $\mathrm{CO}$ intoxication patients can be treated with HBOT in Konya city, which is located in Middle Anatolian region of Turkey. In the hospital where $\mathrm{CO}$ intoxication patients from both Konya and nearby cities are accepted as well as patients from rural areas; children with $\mathrm{CO}$ intoxication are evaluated for the necessity for HBOT following the triage, detailed physical examination and routine labaratory tests (hemogram, blood gases, biochemical parameters) that are done in the emergency department. Patients are consulted with pediatric intensive care, pediatric cardiology and pediatric neurology departments when needed. Patients who and/or whose legal guardians signed the informed consent form to participate in the study were accepted for the study. There were no changes in the routine clinical evaluation and treatment practices of patients specifically made for the present study. The patients were evaluated in two groups as 'patients who received only NBOT'and 'patients who additionally received HBOT'. The number of patients needed for the study was calculated with Gpower programme. The number of subjects needed for each group for $95 \%$ confidence $(1-\alpha), 95 \%$ testing power $(1-\beta)$ and impact power of $\mathrm{d}=0,632$ was $35^{5}$.

\section{Study protocol}

Complete physical examination was performed by collecting detailed medical history from all patients or their relatives. All patients were evaluated by a pediatrician in the pediatric emergency department, HBOT decision was made by an underwater and hyperbaric medicine specialist and ECG evaluations were made by an experienced pediatric cardiology 
specialist. The diagnosis of acute $\mathrm{CO}$ poisoning was made according to medical history, physical examination findings and $\mathrm{COHb}$ level9. When the level of $\mathrm{COHb}$ in the blood was above $10 \%$ in children, $\mathrm{CO}$ poisoning was diagnosed and $100 \% \mathrm{O}_{2}$ (2-5 L/min) was administered (NBOT) via reservoirbag masks. Patients with $\mathrm{COHb}>15 \%$ were treated with HBOT. Patients with symptoms of seizure, syncope, hypotension, or arrhythmia were treated with HBOT regardless of their $\mathrm{COHb}$ levels ${ }^{10}$. HBOT treatment was administered within 3 hours at the latest after admission. HBOT was applied in $12+$ 2 multi-person pressure chamber under the guidance of the internal assistant medical staff. A total of 120 minutes of HBOT was administered including $20 \mathrm{~min}$ of 45 -feet deep compression, $3 \times 25$-min periods of $\mathrm{O}_{2}$ breathing at treatment depth and $15 \mathrm{~min}$ of decompression.

The levels of blood gases, haemograms, biochemical analysis (glucose, blood urea nitrogen, serum creatinine, calcium, magnesium, sodium, potassium, chloride, aspartate aminotransferase, alanine aminotransferase, creatinine kinase-MB and troponin were measured every $3 \mathrm{~h}$ in all patients treated for $\mathrm{CO}$ poisoning following their admission. Troponin levels of $<0.27 \mathrm{ng} / \mathrm{mL}$ were considered to be normal and lactate levels of $\geq 2.2 \mathrm{mmol} / \mathrm{L}$ were considered high ${ }^{11}$. Patients with no complaints, no abnormalities upon physical examination and laboratory assessment, and with control CO levels of $<5 \%$ were considered to be healed.

Those who used anti-arrhythmic drugs or any medication that can prolong QTc, history of congenital heart disease, heart failure, arrhythmia and rheumatic carditis and those who had chronic diseases, electrolyte abnormalities or patients with missing laboratory data were excluded from the study. Approval from the University of Health Sciences Konya Training and Research Hospital (Decision No. 774 dated 03.01.2019) and from KTO Karatay University Medical Faculty Ethics Committee (Decision No. 2019/001 dated 21.02. 2019) was obtained for the study.

\section{Electrocardiography}

ECG recordings of all patients were obtained twice, one during admission and the other 6 hours after the admission. The ECG device was set at $25 \mathrm{~mm} / \mathrm{s}$ speed and $10 \mathrm{~mm} / \mathrm{mV}$ amplitude in all cases. The ECG recordings were physically examined and measurements were made by a cardiologist blinded to each participant. The measurements were made with hand calipers. In all precordial leads, averages were recorded by calculating the $\mathrm{Tp}$-e interval, the $\mathrm{Tp}$-e dispersion and the Tp-e/QT ratio. The distance from the beginning of the QRS to the end of the T-wave was defined as the QT interval. Considering the variations in heart rate according to age, the QTc values corrected using the Bazett formula were calculated $^{12}$. Tp-e was measured in precordial leads using the tangent method. A line is drawn between the second curve of the T-wave and the point where this curve intersects the isoelectric line. The distance between two points measured on the isoelectric line was the Tp-e time (Figure 1).

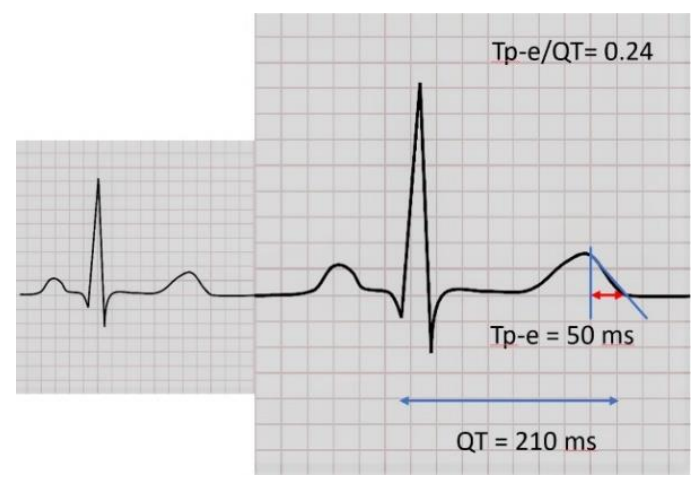

Figure 1. Measurement of Tp-e (The tangent method).

Tp-e dispersion was defined as the difference between the maximum and minimum $\mathrm{Tp}$-e in precordial leads.

\section{Statistical analysis}

All statistical analysis was performed using SPSS 21.0 for Windows (SPSS, Chicago, IL). KolmogorovSmirnov test was applied to determine whether the variables were normally distributed or not. Normally distributed variables are presented as mean \pm SD and the non-normally distributed variables are presented as median and interquartile range. Paired sample ttest was used in patients with normal distribution and Wilcoxon rank test in those without normal distribution to compare the measurement values of NBOT and HBOT groups before and after treatment. The rate of change for each variable was calculated by the ratio of pre-treatment measurement values to post-treatment measurement values. For the comparison of change rates between groups, Student's t-test was used in those with normal distribution and Mann-Whitney's $U$ test was used in 
non-normal distribution. Statistical analyses were performed using two-way hypothesis with a $5 \%$ significance threshold and 95\% confidence interval.

\section{RESULTS}

91 patients were evaluated for this study but 14 patients were excluded from the study due to missing labaratory data. A total of 77 patients diagnosed with
CO poisoning and who met the inclusion criteria were included in this study. The numbers of patients who underwent HBOT and NBOT were 37 (10.6 \pm $4.2 ; 18$ males) and 40 (7.3 \pm 4.1; 23 males), respectively. The two groups were similar in terms of age and gender. Troponin-I levels were high in two patients from the HBOT group and one patient from the NBOT group. There was no difference between the groups in terms of admission levels of $\mathrm{COHb}$, lactate and troponin (Table 1).

Table 1. Baseline characteristics of the treatment groups at admission.

\begin{tabular}{|c|c|c|c|c|c|c|}
\hline \multirow{2}{*}{\multicolumn{2}{|c|}{$\begin{array}{l}\text { mean } \pm \text { SD } \\
\text { median (IQR) }\end{array}$}} & \multicolumn{2}{|c|}{ HBOT Group } & \multicolumn{2}{|c|}{ NBOT Group } & \multirow[b]{2}{*}{$p$} \\
\hline & & \multirow{2}{*}{$\begin{array}{c}\mathrm{n}=37 \\
19\end{array}$} & \multirow{2}{*}{$\begin{array}{c}\mathrm{n}(\%) \\
51.4\end{array}$} & \multirow{2}{*}{$\begin{array}{c}\mathrm{n}=40 \\
17\end{array}$} & \multirow{2}{*}{$\begin{array}{c}\mathrm{n}(\%) \\
42.5\end{array}$} & \\
\hline Sex & Female & & & & & \\
\hline & Male & 18 & 48.6 & 23 & 57.5 & $0.437 t$ \\
\hline \multicolumn{2}{|c|}{ Age (year) } & \multicolumn{2}{|c|}{$10.6 \pm 4.2$} & \multicolumn{2}{|c|}{$7.3 \pm 4.1$} & $0.08^{\dagger}$ \\
\hline \multicolumn{2}{|c|}{$\mathrm{COHb}(\%)$} & \multicolumn{2}{|c|}{$16.4 \pm 11.6$} & \multicolumn{2}{|c|}{$14.4 \pm 7.8$} & $0.367^{+}$ \\
\hline \multicolumn{2}{|c|}{ Lactate $(\mathrm{mmol} / \mathrm{L})$} & \multicolumn{2}{|c|}{$2.19 \pm 1.14$} & \multicolumn{2}{|c|}{$2.16 \pm 0.81$} & $0.909^{\dagger}$ \\
\hline \multicolumn{2}{|c|}{ Troponin (ng/mL) } & \multicolumn{2}{|c|}{$0.040(0.064)$} & \multicolumn{2}{|c|}{$0.020(0.034)$} & $0.302^{*}$ \\
\hline
\end{tabular}

According to the ECG parameters measured at the time of admission as well as those measured after treatment, there was no difference between the groups in terms of Tp-e interval, Tp-e dispersion, corrected QTc and Tp-e/QTc (Table 2). Further, there was no difference between the groups in terms of their rates of post-treatment change in each ECG parameter (Table 3).
None of the children with CO poison had ST changes and arrhythmias. QTc intervals were greater than $440 \mathrm{~ms}$ in eight patients at admission and returned to normal after treatment.

The test power of this study was calculated 96\% (1$\beta$ ), with $95 \%$ confidence $(1-\alpha)$ and $d=0,632$ impact power.

Table 2. Comparison of ECG parameters between HBOT and NBOT groups at admission and discharge

\begin{tabular}{|l|l|c|c|c|}
\hline \multicolumn{2}{|c|}{} & $\begin{array}{c}\text { HBOT Group (n=37) } \\
\text { mean } \pm \text { SD } \\
\text { median (IQR) }\end{array}$ & $\begin{array}{c}\text { NBOT Group (n=40) } \\
\text { mean } \pm \text { SD } \\
\text { median (IQR) }\end{array}$ & $p$ \\
\hline \multirow{2}{*}{ Tp-e (ms) } & Admission & $45(20)$ & $47.50(20)$ & $0.873^{*}$ \\
\cline { 2 - 5 } & Discharge & $45(23)$ & $41(19)$ & $0.141^{*}$ \\
\hline \multirow{2}{*}{ Tp-e disp. (ms) } & Admission & $15(10)$ & $15(10)$ & $0.674^{*}$ \\
\cline { 2 - 5 } & Discharge & $14(10)$ & $10(10)$ & $0.425^{*}$ \\
\hline QTc (msn) & Admission & $390.5 \pm 32.9$ & $395 \pm 32.4$ & $0.550^{* *}$ \\
\cline { 2 - 5 } & Discharge & $379.8 \pm 34.5$ & $385.7 \pm 39.2$ & $0.49{ }^{*}$ \\
\hline \multirow{2}{*}{ Tp-e/QTc } & Admission & $0.131 \pm 0.049$ & $0.127 \pm 0.037$ & $0.677^{* *}$ \\
\cline { 2 - 5 } & Discharge & $0.116(0.07)$ & $0.116(0.04)$ & $0.303^{*}$ \\
\hline
\end{tabular}

* Wilcoxon rank test, $\uparrow$ Paired samples t test, SD: Standard deviation, IQR: Interquartile range, Tp-e: Distance from the peak to the end of the $\mathrm{T}$ wave on the isoelectric line, Tp-e dispersion: Difference between the maximum and minimum Tp-e distance on the isoelectric line. 
Table 3. Comparison of ECG and blood gas parameters change ratios between HBOT and NBOT groups.

\begin{tabular}{|c|c|c|c|}
\hline & $\begin{array}{c}\text { HBOT Group }(\mathrm{n}=37) \\
\text { mean } \pm \mathrm{SD} \\
\text { median }(\mathrm{IQR})\end{array}$ & $\begin{array}{c}\text { NBOT Group }(\mathrm{n}=40) \\
\text { mean } \pm \text { SD } \\
\text { median }(\mathrm{IQR})\end{array}$ & $p$ \\
\hline Tp-e (ms) & $1(0.56)$ & $1.05(0.40)$ & $0.238^{*}$ \\
\hline Tp-e dispersion (ms) & $1(1.33)$ & $1.32(1.31)$ & $0.780^{*}$ \\
\hline QTc (ms) & $0.99(0.16)$ & $1.04(0.18)$ & $0.501 t^{t}$ \\
\hline Tp-e/QTc & $1.02 \pm 0.46$ & $1.07(0.41)$ & $0.638^{\dagger}$ \\
\hline $\mathrm{COHb}(\%)$ & 17.5 (34.6) & $10(30.5)$ & $0.067+$ \\
\hline Lactate $(\mathrm{mmol} / \mathrm{L})$ & $1.37(0.83)$ & $1.41(0.96)$ & $0.779 \dagger$ \\
\hline $\mathrm{PH}$ & $0.99(0.01)$ & $0.99(0.01)$ & $0.463^{\dagger}$ \\
\hline $\mathrm{HCO}_{3}(\mathrm{mmol} / \mathrm{L})$ & $0.97 \pm 0.08$ & $1 \pm 0.12$ & $0.236^{*}$ \\
\hline $\mathrm{BE}$ & $1.25(1.48)$ & $1.22(0.87)$ & $0.245^{t}$ \\
\hline
\end{tabular}

* Mann Whitney-U test, $†$ Student t-test, SD: Standard deviation, IQR: Interquartile range, Tp-e: Distance from the peak to the end of the $\mathrm{T}$ wave on the isoelectric line, Tp-e dispersion: Difference between the maximum and minimum Tp-e distance on the isoelectric line, HCO3: Bicarbonate, BE: Base excess.

\section{DISCUSSION}

CO poisoning is among the most important causes of poisoning all over the world due to its prevalence and high morbidity and mortality rates. Although its effects on the human body are extensive, the brain and heart are the two vital organs that are the most affected by CO poisoning. Significant course of neurological manifestations can make it difficult to detect cardiotoxicity ${ }^{13}$. Therefore, cardiovascular examination is important in patients with $\mathrm{CO}$ poisoning. $\mathrm{CO}$ poisoning can exert its effect on myocardium via two main mechanisms. The first effect is hypoxia caused by $\mathrm{COHb}$. $\mathrm{COHb}$, formed during intoxication, shifts the haemoglobin dissociation curve and tissue hypoxia occurs ${ }^{14}$. The other effect of $\mathrm{CO}$ on the heart is its cardiotoxic effect. This effect occurs via the inhibition of cytochrome $\mathrm{C}$ oxidase, free radical increase and nitric oxide formation. Depending on the degree of toxic effect, myocardial damage can be reversible or irreversible $3,15,16$.

Changes in the myocardial tissue due to $\mathrm{CO}$ might result in clinical problems of the cardiovascular system, such as tachycardia, dysrhythmia, hypotension, heart failure, acute myocardial infarction, cardiomyopathy, myocardial rupture and cardiac arrest ${ }^{9,17-20}$. Despite the wide range of clinical manifestations, the symptoms and signs of $\mathrm{CO}$ poisoning may not manifest in each patient, or findings related with other systems may prevent cardiotoxicity findings from being detected ${ }^{3}$. The low diagnostic value of myocardial damage biomarkers in identifying $\mathrm{CO}$-poisoning-related myocardial damage as well as nonspecific ECG changes make the diagnosis even more difficult ${ }^{21}$.

In acute $\mathrm{CO}$ poisoning, repolarisation changes, such as ST-T changes and QT interval prolongation on ECG and signs of arrhythmia are often observed. QT and QT dispersion are indicators of heterogeneous myocardial repolarisation, and heterogeneity of myocardial repolarisation can play a major role in the pathogenesis of arrhythmia developing in cases of $\mathrm{CO}$ poisoning ${ }^{4,22,23}$. In studies on rats, $\mathrm{CO}$ can cause a pro-arrhythmic effect by causing irregularity in calcium metabolism of epicardial myocytes ${ }^{24}$. The phases of repolarisation in different parts of the myocardium are different, and pathological changes occurring in these zones can lead to trans-myocardial heterogeneity, thereby causing arrhythmias. Tpe/QT ratio, Tp-e interval and $\mathrm{Tp}-\mathrm{e}$ dispersion are new parameters that define trans-myocardial heterogeneity and are superior to QT interval and QT dispersion for predicting arrhythmias. Previously, it was reported that the duration of these parameters and the Tp-e/QT ratio increased in both short and long QT syndrome, Brugada syndrome and myocardial infarction ${ }^{25,26}$. The extension of the Tp-e interval increases the risk of developing arrhythmia ${ }^{27}$. In a study that evaluated the records of adults patients with sudden cardiac death, the increase in $\mathrm{Tp}$-e interval ( $\mathrm{Tp}$-e $>85 \mathrm{~ms}$ ) and the increase in Tp-e/QT ratio were associated with sudden cardiac death ${ }^{28}$. Tp- 
e dispersion is an indicator of the variability of transmyocardial repolarisation in different areas of the myocardium and increases the likelihood of developing arrhythmia, especially in patients with canopathy 25,26

Earlier studies on adults with $\mathrm{CO}$ poisoning reported increased Tp-e interval, Tp-e dispersion and $\mathrm{Tp}$ e/QT ratio ${ }^{5,6}$. In a study where Ak1llı et al. followed up adult patients with $\mathrm{CO}$ poisoning, the admission values of $\mathrm{Tp}$-e interval, Tp-e dispersion and $\mathrm{Tp}$ e/QT ratio in all patients administered NBOT were higher than the values at the $6^{\text {th }}$ and $24^{\text {th }}$ and that of the healthy control group 5 . As a result, it has been suggested that a prolonged Tp-e interval may be an indicator of myocardial damage. Özyurt et al. compared a group of 22 children with CO poisoning with a control group of 24 healthy children and reported that their admission Tp-e, QTc, Tp-e dispersion and $\mathrm{Tp}-\mathrm{e} / \mathrm{QT}$ ratio were significantly higher than the healthy control group, and the values measured at the end of a mean 3.4-day hospital stay following NBOT significantly reduced compared to their admission values and all QTc periods were normalised ${ }^{7}$. Both the above-mentioned studies were conducted only on patients treated with NBOT.

The present study compares patients with $\mathrm{CO}$ poisoning who were treated with HBOT for having HBOT indication or with NBOT for having NBOT indication depending on their clinical and laboratory findings. There was no difference between the groups in terms of their admission levels of $\mathrm{COHb}$, troponin and lactate, which can be explained by the fact that CO level was ignored when making HBOT decision in patients with neurological findings and with the indication limit for HBOT relatively being as low as $15 \%$.

The degree of hyper-oxygenation is higher in HBOT than in NBOT. Despite the significant effects of $\mathrm{O} 2$ therapy, late changes after $\mathrm{CO}$ poisoning have been associated with ischemic reperfusion injuries ${ }^{8}$. Reoxygenation injury may occur following CO-related tissue hypoxia. Hyper-oxygenation facilitates the production of reactive oxygen species and leads to typical reperfusion damage via oxidation of the macromolecules within the cell. Oxidised lipid products, proteins and nucleic acids are important evidence of oxidative reperfusion damage after hyperbaric treatment of $\mathrm{CO}$ poisoning. These cytotoxic products lead to the accumulation of inflammatory leukocytes in the tissue as well as further injuries and cell deaths secondary to both micro-necrosis and apoptosis ${ }^{29-31}$. The reason for not finding a significant difference in terms of ECG parameters between the two groups in our study may be the reperfusion damage that develops due to HBOT and increases the degree of myocardial injury, despite the beneficial effects of $\mathrm{O} 2$.

Tintinalli et al. reported that asymptomatic patients admitted with CO poisoning should be monitored for at least $4 \mathrm{~h}$, while Ak1ll et al. recommended that patients with long $\mathrm{Tp}$-e should be monitored for myocardial damage and arrhythmia for $>4 \mathrm{~h}$. None of the cases included in our study had Tp-e times of $>85 \mathrm{~ms}^{5,32}$

The fact that the study is a monocentric study that included relatively small number of patients, ECG measurements were performed by a cardiologist and the lack of echocardiographic evaluation of patients due to financial constraints are among the limitations of the study. Despite limitations, this study was the first to evaluate the effects of NBOT and HBOT on ECG parameters in adults and children with CO poisoning. It is therefore an important study that will constitute a basis for further studies to be conducted that are focused on this issue.

Our study is the first in literature to compare the effects of HBOT and NBOT on ECG parameters in patients with $\mathrm{CO}$ poisoning. This study revealed that the effects of HBOT administered in children with $\mathrm{CO}$ poisoning on trans-myocardial repolarisation parameters of ECG did not differ from the effects observed in children treated only with NBOT. The fact that the expected positive effects of HBOT therapy on ECG parameters are not that distinct and satisfying can be explained by the reperfusion damage that might probably have developed due to the degree of hyper-oxygenation. To reveal the possible effects of HBOT on ECG parameters and myocardial injury, there is a need for more comprehensive studies that include methods, such as echocardiography, holter study, myocardial scintigraphy and cardiac MRI.

Yazar Katkıları: Çalışma konsepti/Tasarımı: ZB; Veri toplama: ZB, $\mathrm{DA}, \mathrm{AKD}$; Veri analizi ve yorumlama: $Z \mathrm{~B}, \mathrm{AA}$; Yazı taslağı: $Z \mathrm{~B}, \mathrm{AKD}$; İçeriğin eleştirel incelenmesi: $\mathrm{ZB}, \mathrm{DA}$; Son onay ve sorumluluk: $\mathrm{ZB}$, AA, DA, AKD; Teknik ve malzeme desteği: AA; Süpervizyon: ZB, AA; Fon sağlama (mevcut ise): yok.

Etik Onay: Bu çalışma için KTO Kartay Ünivresitesi Tip Fakültesi İlaç ve Tibbi Cihaz Dışı Araştırmalar Etik Kurulundan 21.02.2019 tarih ve 2019/001-02 sayılı kararı ile etik onay alınmıștır.

Hakem Değerlendirmesi: Dıș bağımsız.

Cıkar Çatışması: Yazarlar çıkar çatısması beyan etmemişlerdir.

Finansal Destek: Yazarlar finansal destek beyan etmemişlerdir. 
Author Contributions: Concept/Design : ZB; Data acquisition: ZB, $\mathrm{DA}$, AKD; Data analysis and interpretation: $\mathrm{ZB}$, AA; Drafting manuscript: $Z B, A K D$; Critical revision of manuscript: $Z B, D A$; Final approval and accountability: ZB, AA, DA, AKD; Technical or material support: AA; Supervision: $\mathrm{ZB}, \mathrm{AA}$; Securing funding (if available): $\mathrm{n} / \mathrm{a}$. Ethical Approval: For this study, ethical approval was obtained from the Ethics Committee of the Faculty of Medicine of the KTO Kartay Univresity on Pharmaceutical and Non-Medical Device Research dated 21.02.2019 and numbered 2019/001-02

Peer-review: Externally peer-reviewed.

Conflict of Interest: Authors declared no conflict of interest.

Financial Disclosure: Authors declared no financial support

\section{REFERENCES}

1. Raub JA, Mathieu-Nolf M, Hampson NB, Thom SR. Carbon monoxide poisoning-a public health perspective. Toxicology. 2000;145:1-14.

2. Blumenthal I. Carbon monoxide poisoning. J R Soc Med. 2001;94:270-2.

3. Aslan S, Uzkeser M, Seven B, Gundogdu F, Acemoglu $\mathrm{H}$, Aksakal $\mathrm{E}$ et al. The evaluation of myocardial damage in 83 young adults with carbon monoxide poisoning in the East Anatolia region in Turkey. Hum Exp Toxicol. 2006;25:439-46.

4. Yelken B, Tanriverdi B, Cetinbas F, Memis D, Sut N. The assessment of QT intervals in acute carbon monoxide poisoning. Anatolian J Cardiol. 2009;9:397400.

5. Akilli NB, Akinci E, Akilli H, Dundar ZD, Koylu R, Polat $\mathrm{M}$ et al. A new marker for myocardial injury in carbon monoxide poisoning: $\mathrm{T}$ peak- $\mathrm{T}$ end. Am J Emerg Med. 2013;31:1651-5.

6. Eroglu M, Yildirim AO, Uz O, Isilak Z, Yalcin M, Kardesoglu E. Carbon monoxide poisoning increases Tpeak-Tend dispersion and QTc dispersion. Cardiovasc J Afr. 2014;25:106.

7. Ozyurt A, Karpuz D, Yucel A, Tosun MD, Kibar AE, Hallioglu O. Effects of acute carbon monoxide poisoning on ECG and echocardiographic parameters in children. Cardiovasc Toxicol. 2017;17:326-34.

8. Akyol S, Erdogan S, Idiz N, Celik S, Kaya M, Ucar F et al. The role of reactive oxygen species and oxidative stress in carbon monoxide toxicity: an in-depth analysis. Redox Rep. 2014;19:180-9.

9. Lippi G, Rastelli G, Meschi T, Borghi L, Cervellin G. Pathophysiology, clinics, diagnosis and treatment of heart involvement in carbon monoxide poisoning. Clin Biochem. 2012;45:1278-85.

10. Mathieu D, Marroni A, Kot J. Tenth European Consensus Conference on Hyperbaric Medicine: recommendations for accepted and non-accepted clinical indications and practice of hyperbaric oxygen treatment. Diving Hyperb Med. 2017;47:24-32.

11. Besli GE, Erguven M, Karadogan M, Yılmaz Ö. Çocuklarda karbon monoksit zehirlenmesi. Akademik Acil Tip Olgu Sunumlar1 Dergisi. 2010;9:26-30.

12. Qiu H, Bird GL, Qu L, Vetter VL, White PS, Evaluation of QT interval correction methods in normal pediatric resting ECGs. in 2007 Computers in Cardiology. Durham, NC, USA: IEEE.

13. Adir Y, Merdler A, Haim SB, Harduf R, Bitterman H. Effects of exposure to low concentrations of carbon monoxide on exercise performance and myocardial perfusion in young healthy men. Occup Environ Med. 1999;56:535-8.

14. Douglas C, Haldane J, Haldane J. The laws of combination of haemoglobin with carbon monoxide and oxygen. J Physiol. 1912;44:275-304.

15. Prockop LD, Chichkova RI. Carbon monoxide intoxication: an updated review. J Neurol Sci. 2007;262:122-30.

16. Tritapepe L, Macchiarelli G, Rocco M, Scopinaro F, Schillaci O, Martuscelli E et al. Functional and ultrastructural evidence of myocardial stunning after acute carbon monoxide poisoning. 1998;26:797-801.

17. Satran D, Henry CR, Adkinson C, Nicholson CI, Bracha Y, Henry TD. Cardiovascular manifestations of moderate to severe carbon monoxide poisoning. J Am Coll Cardiol. 2005;45:1513-6.

18. Kalay N, Ozdogru I, Cetinkaya Y, Eryol NK, Dogan A, Gul I et al. Cardiovascular effects of carbon monoxide poisoning. Am J Cardiol. 2007;99:322-4.

19. Dragelyte G, Plenta J, Chmieliauskas S, Jasulaitis A, Raudys R, Jovaisa $\mathrm{T}$ et al. Myocardial rupture following carbon monoxide poisoning. Case Rep Crit Care. 2014;2014:281701.

20. Teksam O, Gumus P, Bayrakci B, Erdogan I, Kale G. Acute cardiac effects of carbon monoxide poisoning in children. Eur J Emerg Med. 2010;17:192-6.

21. Gandini C, Castoldi AF, Candura SM, Locatelli C, Butera R, Priori $\mathrm{S}$ et al. Carbon monoxide cardiotoxicity. J Toxicol Clin Toxicol. 2001;39:35-44.

22. Carnevali R, Omboni E, Rossati M, Villa A, Checchini M. Electrocardiographic changes in acute carbon monoxide poisoning. Minerva Med. 1987;78:175-8.

23. Hajsadeghi S, Tavakkoli N, Kerman SRJ, Shahabadi A, Khojand M. Electrocardiographic findings and serum troponin I in carbon monoxide poisoned patients. Acta Med Iran. 2012;50:185-91.

24. Andre L, Boissiere J, Reboul C, Perrier R, Zalvidea S, Meyer $G$ et al. Carbon monoxide pollution promotes cardiac remodeling and ventricular arrhythmia in healthy rats. Am J Respir Crit Care Med. 2010;181:587-95

25. Gupta P, Patel C, Patel H, Narayanaswamy S, Malhotra B, Green JT et al. Tp-e/QT ratio as an index of arrhythmogenesis. J Electrocardiol. 2008;41:56774.

26. Castro Hevia J, Antzelevitch C, Tornes Barzaga F, Dorantes Sanchez M, Dorticos Balea F, Zayas Molina $\mathrm{R}$ et al. Tpeak-Tend and Tpeak-Tend dispersion as risk factors for ventricular tachycardia/ventricular fibrillation in patients with the Brugada syndrome. J Am Coll Cardiol. 2006;47:1828-34. 
27. Yan GX, Antzelevitch C. Cellular basis for the normal $\mathrm{T}$ wave and the electrocardiographic manifestations of the long-QT syndrome. Circulation. 1998;98:1928-36.

28. Panikkath R, Reinier K, Uy-Evanado A, Teodorescu C, Hattenhauer J, Mariani R et al. Prolonged Tpeakto-tend interval on the resting ECG is associated with increased risk of sudden cardiac death. Circ Arrhythm Electrophysiol. 2011;4:441-7.

29. Kavakli HS, Erel O, Delice O, Gormez G, Isikoglu S, Tanriverdi F. Oxidative stress increases in carbon monoxide poisoning patients. Hum Exp Toxicol. 2011;30:160-4.
30. Sun Q, Cai J, Zhou J, Tao H, Zhang JH, Zhang W et al. Hydrogen-rich saline reduces delayed neurologic sequelae in experimental carbon monoxide toxicity. Crit Care Med. 2011;39:765-9.

31. Knauert M, Vangala S, Haslip M, Lee PJ. Therapeutic applications of carbon monoxide. Oxid Med Cell Longev. 2013;2013:360815.

32. Tintinalli JE, Kelen GD, Stapcy.zynski SJ. Carbon monoxide poisoning. In Emergency Medicine: A Comprehensive Study Guide (Eds Tintinalli JE, Kelen GD, Stapcyzynski SJ):1302-6. North Carolina: McGraw-Hill, 2000. 